\title{
Ruang Kontemplasi Sebagai Sarana dan Berapresisasi dengan Media Ruang Arsitektur yang Impresif
}

\author{
Kelik Hendro Basuki ${ }^{1 *}$ \\ ${ }^{1}$ Program Studi Arsitektur, Fakultas Teknik, Universitas Lampung \\ *Penulis Korespondensi: kelik.hendro@eng.unila.ac.id; Telp. +62 813-7974-6399
}

\begin{abstract}
Abstrak:
Kompleksitas kebutuhan masyarakat urban dapat diwadahi oleh ruang yang kontekstual terhadap kebutuhan fisik dan non-fisik, jiwa dan raga, place dan space, bahkan masa lalu dan masa depan. Sehingga simbiosis dari seluruh kebutuhan tersebut mampu terangkum dalam satu wadah yang ekspresif dan apresiatif terhadap kebutuhan masyarakat urban. Masyarakat urban dalam konteks budaya 'leisure' membutuhkan ciptaan ruang yang impresif dan kontemplatif sebagai cerminan pemanfaatan waktu yang berharga. Untuk memanfaatkan waktu tersebut, dapat diakomodasi oleh ruang kontemplasi dimana kebutuhan jiwa sebagai hal yang mendasar memerlukan sesuatu yang impresif yang memberikan dampak terhadap jiwa. Sehingga dapat memandang jauh ke depan untuk mengisi 'hidup' lebih bermakna, dapat menciptakan sesuatu yang 'indah' (pemikiran, tindakan, dan karya), serta mampu mangambil bagian dalam hidup sebagai pengejawantahan makna dari 'hidup itu indah'. Masyarakat urban yang sibuk dengan urusan karya dan bisnisnya terkadang merindukan waktu-waktu khusus untuk pemenuhan relaksasi jiwa sebagai upaya keseimbangan hidup antara kebutuhan jasmani dan rohani. Eksistensi dan apresiasi seni dan budaya merupakan suatu kebutuhan yang dapat diwadahi oleh ruang arsitektur sebagai wahana berkreasi, berekspresi, berelaksasi, bermeditasi dalam wujud berkontemplasi. Ekspresi sebagai jiwa dari proses kreatif dan apresiasi sebagai bagian dari pemahaman dan penikmatan, memerlukan media yang berupa ruang arsitektur yang impresif sebagai sarana berkontemplasi dalam konteks seni dan budaya.
\end{abstract}

Kata Kunci: Apresiasi, Ekspresi, Impresif, Ruang Kontemplasi

\section{Latar Belakang}

Ruang kontemplasi diterjemahkan sebagai tempat/wadah manusia untuk berdiam diri dalam keheningan, pencarian akan suatu kebenaran hakiki serta perenungan akan suatu kejadian/fenomena yang mengusik sisi emosinal, rasanya memang selalu bisa menjadi wadah penyeimbang rutinitas aktifitas bagi masyarakat urban yang memiliki banyak waktu luang ataupun sebagai pengisi waktu antara.

Komunitas seni dan budaya tertentu telah terintegrasi dengan kehidupan kota di Negara ini. Komunitas seni dan budaya telah memberikan warna baru terhadap perekonomian dan budaya urban baik di kota-kota besar maupun kota yang relatif sedang berkembang. Fenomena masyarakat non-pribumi yang telah menerima bahkan menikmati seni dan budaya pribumi terindikasi dari semakin banyaknya kegiatan dan ekshibisi seni dan budaya setempat. Juga masyarakat urban dalam melaksanakan rutinitas kegiatan karya dan bisnisnya terkadang lupa akan waktu, sehingga jarang dari mereka dapat meluangkan waktu untuk mencoba menuangkan seni dan budaya mereka dalam kehidupan sehari-hari.

Hal tersebut membuka sebuah peluang besar untuk menghadirkan sebuah ruang yang mampu mengakomodir kebutuhan untuk berkespresi dan berapresiasi (Basuki, 2012) dalam konteks seni dan budaya sebagai upaya memberikan akupuntur terhadap sebuah kawasan/kota yang kegiatan karya, ekonomi, dan kehidupan kotanya dilakukan oleh masyarkat urban.

Dengan adanya 'ruang kontemplasi seni dan budaya' tersebut, komunitas tertentu bahkan masyarakat di luar komunitas tersebut dapat berekspresi dan berapresiasi serta melakukan relaksasi jiwa di fasilitas tersebut, sehingga pemenuhan kesehatan jasmani dan rohani dapat tercapai.

Sehingga menjawab kebutuhan akan ruang kontemplasi yang impresif dengan merujuk pernyataan Helm II (2007) bahwa, 'arsitek dapat men-sakral-kan lokasi dengan mengumpulkan impresi sensorik yang bermakna bagi individu dan lokasi, dan menuangkan impresi tersebut ke dalam solusi desain, sehingga tercipta sebuah ruang kontemplasi'.

Pernyataan di atas, dapat menjadi sebuah pendekatan perancangan arsitektur, dengan melibatkan impresi sensorik yang bermakna untuk menciptakan sebuah ruang kontemplasi yang impresif. Sehingga tujuan dari penelitian ini, mencoba melakukan pendekatan pada ruang, yang menandai eksistensi menusia sebagai subyek yang sadar untuk mengamati dan menjadi kendaraan 'being in the world', dalam konteks seni dan budaya. 


\section{Metode}

Metode pendekatannya adalah metode kualitatif berupa metode fenomenologi persepsi. Diharapkan dapat mengungkapkan keingintahuan terhadap fenomena yang terjadi terhadap subyek akan kebutuhan ruang untuk berkontemplasi, dan persepsi-persepsi kebutuhan berkontemplasi yang menjadi esensi dari makna topik dan permasalahan yang ada.

\subsection{Metode Pengumpulan Data}

Metode Pengumpulan data yang digunakan dalam penelitian ini adalah sebagai berikut:

1. Studi Literatur; melakukan kajian literatur sebagai acuan standar perancangan serta mendapatkan teori-teori yang mendukung isu ruang kontemplasi dan isu pendukung lainnya.

2. Browsing; melakukan eksplorasi literatur di internet sebagai data sekunder untuk mendapatkan teori-teori dan fakta yang mendukung isu ruang kontemplasi dan isu pendukung lainnya.

Studi Preseden; mengkaji fasilitas sejenis yang berkaitan dengan ruang kontemplasi, nilai lokal yang diterapkan dalam desain, bentukan fisik ruang dan bangunan yang memiliki fasilitas kontemplatif, dan sampai hal-hal yang harus dihindari dalam ruang kontemplasi.

\subsection{Metode Analisis Data}

Melihat fenomena yang terjadi berkaitan dengan aspek-aspek kajian fenomenologi persepsi dan studi kasus, untuk mendapatkan dan merumuskan esensi analisis permasalahan dan pemecahannya. Mencari rumusan sebuah ruang kontemplasi pada sebuah fasilitas seni dan budaya yang berisikan kegiatan berekspresi dan berapresiasi, dengan memasukan unsur pemaksimalan indera dan rasa, sehingga tercipta ruang kontemplasi yang impresif.

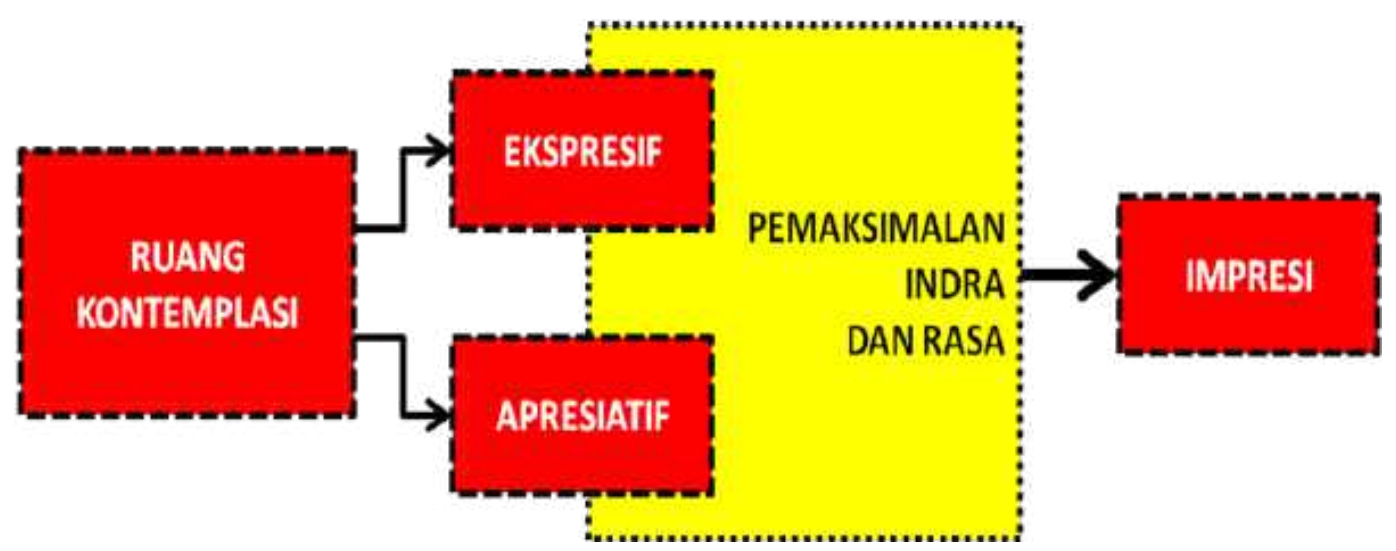

Gambar 1. Metode Pendekatan

\section{Hasil dan Pembahasan}

Dari pengertian beberapa sumber dan referensi dapat dirumuskan bahwa ruang kontemplasi adalah wadah untuk menciptakan sesuatu yang indah; wadah untuk dapat memandang jauh ke depan demi mendapatkan arah dan kemungkinan tindakan lain (antisipasi) yang lebih bermakna; wadah untuk berbuat suatu tindakan untuk memahami penuh suatu hal; wadah untuk dapat memandang sesuatu dengan cara ambil bagian dalam hidup, dalam adegan, dan terlibat langsung.

\subsection{Gambaran Umum Ruang Kontemplasi}

Ruang kontemplasi banyak diciptakan yang berkaitan dengan keagamaan dan meditasi, namun beberapa ruang kontemplasi juga diciptakan bukan hanya sekedar untuk bermeditasi, akan tetapi sebagai sarana untuk mengenang tragedi kemanusiaan, hingga sebagai sarana mencipta dan aktualisasi diri yang berkaitan dengan sesuatu yang indah (seni). Berikut ini beberapa contoh bentuk fisik dari implementasi ruang kontemplasi: 
1) M-velope (Michael Jantzen): sebuah karya yang diciptakan khusus untuk bermeditasi.

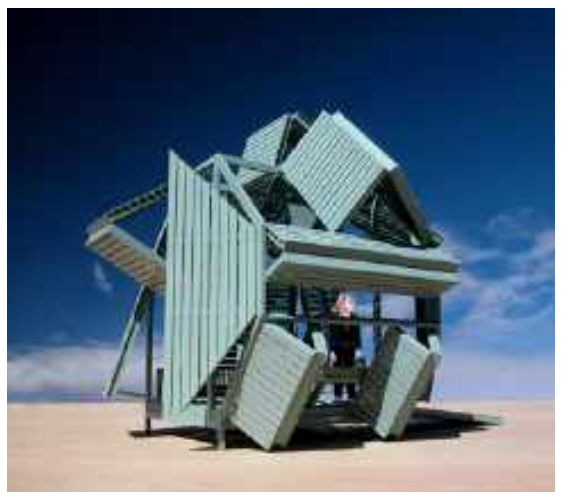

Gambar 2. M-velope

2) The World Trade Center Memorial Design (Lynn Jericho and Carol Allen): proposal untuk mengenang tragedi WTC sebagai titik balik dari kejadian yang berakhir tragis, proposal ini memberikan inspirasi baru tentang suatu kehidupan dan masa depan serta peran setiap individu dalam membentuk dunia kita. (mengingat masa lalu membayangkan masa depan)

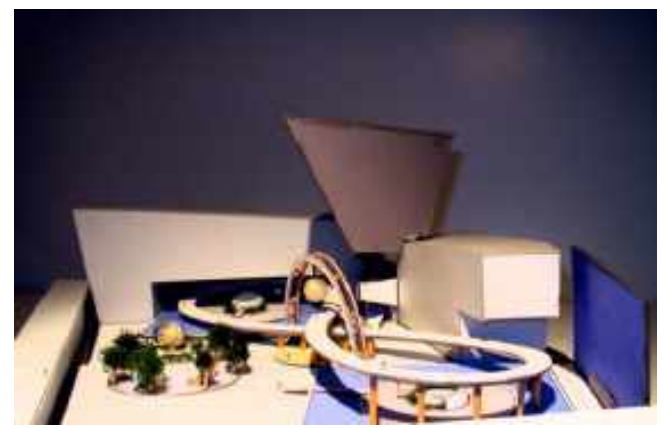

Gambar 3. World Trade Center Memorial Design

3) Ruang Bawah Tanah Lawang Sewu; pengunjung yang masuk ke dalam ruang bawah tanah gedung Lawang Sewu yang berada di Semarang diajak untuk melihat bagaimana sel-sel penyiksaan tentara Jepang terhadap tentara kita yang sangat sadis, dengan disertai cerita-cerita pendukungnya. Setelah itu pengunjung diajak berhenti sejenak ( \pm 5 menit) untuk merenung dalam kondisi ruang yang sangat gelap. Disana pengunjung dapat merasakan suasana yang sangat hening yang membawa alam pikiran kita terhadap kejadian dimasa lalu, untuk bersyukur atas kehidupan dimasa depan.

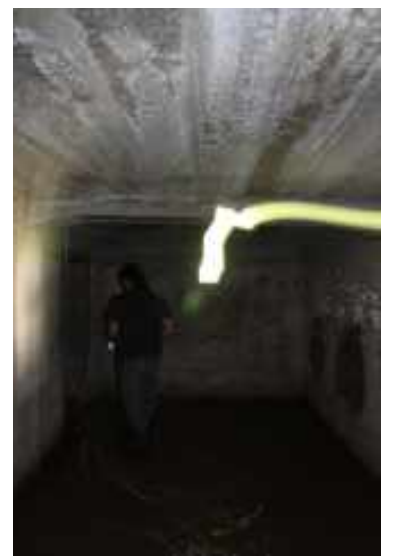

Gambar 4. Ruang Bawah Tanah Lawang Sewu

4) Tadao Ando's cylindrical; satu cerita "Ruang untuk Kontemplasi" di kompleks UNESCO, Paris, upaya untuk mengungkap "memori lokasi" dengan mempertahankan kesadaran tentang hubungan baru, karya arsitektur yang dapat membuat hubungan antara sejarah, kota, dan masyarakat (ledakan bom Hiroshima). 


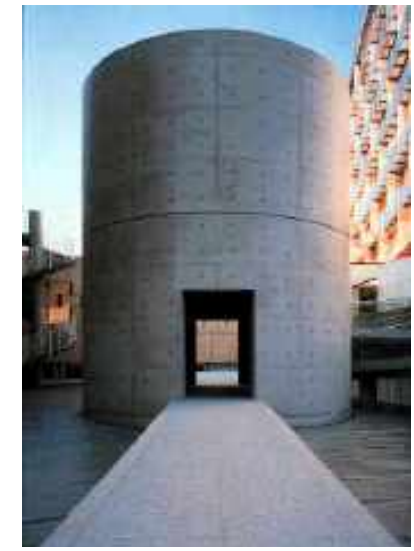

Gambar 5. Tadao Ando's Cylindrical

5) A loftier contemplation of architecture and anatomy; seorang seniman (Richard Serra) yang meletakan patung diluar halaman Museum Modern of Art, yang membuat pengunjung tertarik melihat melalui jendela museum tersebut.

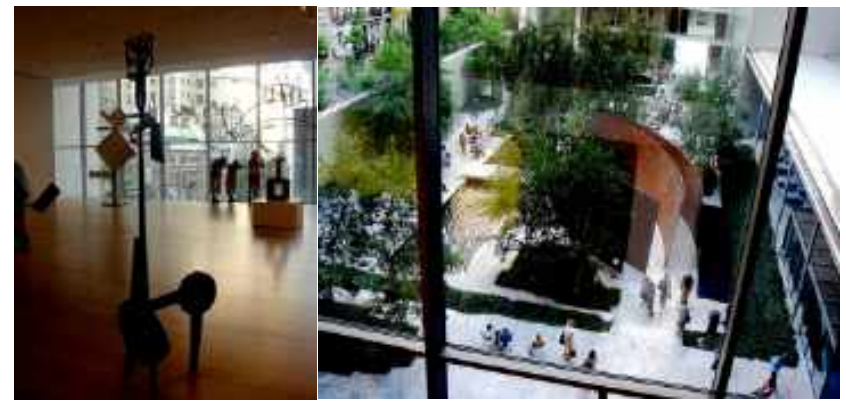

Gambar 6. Museum Modern of Art

\subsection{Pendekatan Kontemplatif Qolbu}

Menurut Herry Santosa (2010), Pendekatan kontemplatif qolbu terbagi dalam tiga impresi, yaitu:

1) Akal: merupakan impresi pertama. Berisi hasil upaya manusia untuk mempelajari alam, ilmu pengetahuan, teknologi, filosofi, dan lain-lain. Dicapai melalui upaya mempelajari kejadian-kejadian alam, pemikiran, logika, serta perumusannya.

2) Rasa: merupakan impresi kedua. Berisi kaidah-kaidah dalam tata sosial budaya masyarakat seperti norma, etika, adat, dan melibatkan rasa inderawi. Dibentuk oleh system tatanan sosial dalam organisasi masyarakat dan oleh inderawi manusia.

3) Qalbu: merupakan impresi ketiga dan tertinggi. Merupakan tempat bersemayam-nya roh dimasukkan Tuhan (setelah mengadakan perjanjian dengan Tuhan) ke dalam tubuh manusia. Ruang qolbu merupakan ruang penjelajahan jiwa yang paling dalam dan merujuk pada esensi kebenaran (keindahan) yang hakiki, dengan pengakuan atas Tuhan sebagai kekuatan tunggal, penguasa jagad raya. 


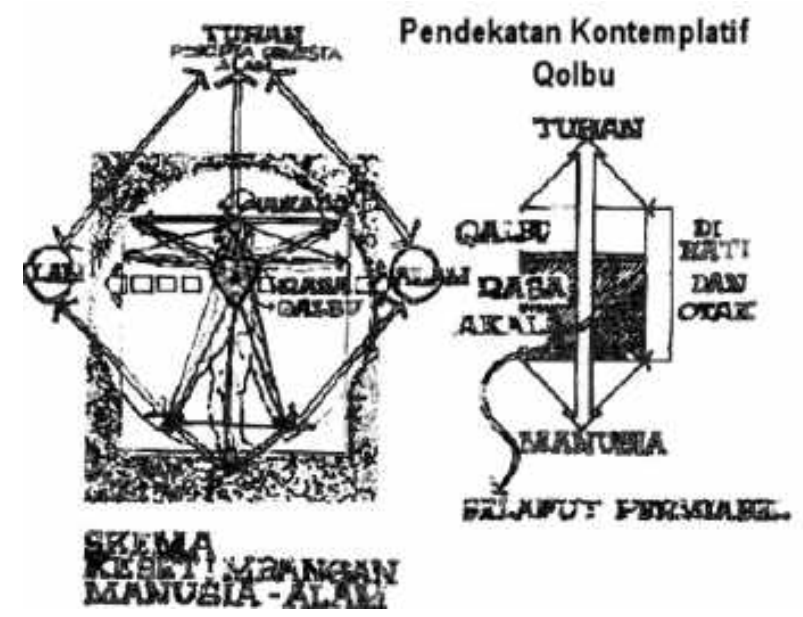

Gambar 7. Pendekatan Kontemplatif Qolbu

\subsection{Pendekatan Fenomenologi Persepsi}

Persepsi adalah proses aktif melalui mana kita memahami dunia di sekitar kita. Untuk melakukan hal ini tentu saja kita mengandalkan sensasi, tapi kita biasanya mengintegrasikan pengalaman dari semua indera kita tanpa analisis sadar. Hal ini hanya ketika ada sesuatu yang tidak biasa atau keluar dari tempat yang kita perhatikan berbeda sensasinya, perbedaan perhatian kita itu, dan apapun itu merupakan keharmonian (Lawson, 2001).

Dalam teori Merleau-Ponty, yang menjadi tujuan utamanya mengenai 'Phenomenology of Perception' adalah :

1) Karakterisasi struktur eksistensial manusia sebagai "being-in-the-world".

2) Dalam upaya memfasilitasi karakterisasi ini, ia menekankan arti pentingnya hidup yang mendasar dari tubuh kita, tubuh sebagai kesadaran atau subyek yang mengamati, bukannya tubuh sebagai obyek yang dirasakan, seperti sarana/kendaraan kita dari 'being-in-the-world'. Bagaimanapun, dalam sebuah investigasi pendekatan fenomenolgi tentang persepsi, tubuh dan 'being-in-the-world', sangatlah luar biasa, bahwa Merleau-Ponty memberi beberapa perhatian yang substansial kepada analisis pendekatan fenomenologis keruangan.

3) Walaupun permasalahan dalam ruang sedemikian rupa, tegasnya, itu bukanlah masalah utama dalam fenomenologi persepsi jika dibenarkan bagi kita untuk merekonstruksi sebuah 'fenomenologi ruang' (Liu Shengli).

Sebuah rumah atau ruang yang sudah 'berpengalaman' bukanlah sebuah kotak yang tidak bergerak. Ruang yang dihuni melampaui ruang geometris (Bachelard, 1969). Dari teori tersebut menggambarkan sebuah ruang dipenuhi dengan nilai-nilai yang juga tak terukur, selain dari batasan geometri ruang. Ruang dipenuhi dengan 'keintiman', 'kosmisitas', dan terintegrasi terhadap seluruh sensasi ruang.

\subsection{Studi Preseden}

\section{Meditation Space, Unesco-Paris}

Ruang Meditasi ini dirancang oleh Tadao Ando untuk kantor pusat Unesco di Paris pada tahun 1995. Ruang meditasi yang dirancang terletak di tengah bangunan lainnya, dimana lokasi berada di lingkungan yang cukup ramai.

Ruang meditasi utama berbentuk silinder, kecil, dan sederhana. Luas totalnya $33 \mathrm{~m} 2$ dengan ketinggian 6 meter. Strukturnya tampak secara harfiah seperti silinder beton dengan dua pintu di sisi yang berlawanan. Pintu-pintu tersebut berukuran biasa, yang memungkinkan cahaya dalam jumlah terbatas yang masuk ke dalam ruang. Struktur silinder diibaratkan seperti kandungan yang pernah pengunjung masuki, mereka berada di ruang yang aman dan 'independen', yang bukan bagian dari dunia. Tidak ada dekorasi di dalamnya yang mungkin akan mengganggu pengunjung, sehingga pengunjung bisa fokus pada dunia rohani mereka dan melihat jauh ke dalam jiwa mereka pada saat di dalam ruang ini. Bentuk silinder kecil di anggap melambangkan inti dari jiwa manusia, polos, murni, dan sederhana. Kesederhanaan, rendah hati dan bahkan suasana remang yang ada membuat kita mulai mencari, kita akan menemukan kesan pertama yang benar-benar menceritakan banyak hal. 


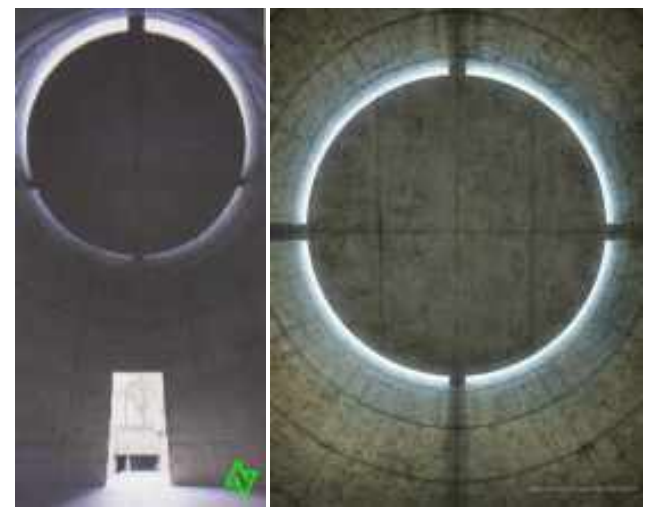

Gambar 8. Ruang Dalam Ruang Meditasi

Ada dua kesan "mengambang" dalam ruang meditasi ini. Yang pertama adalah kolam air di luar silinder. Dengan adanya sinar matahari, airnya bersinar, sehingga terlihat ruang meditasi yang berbentuk silinder putih tersebut seperti mengambang di atas permukaan yang bersinar emas. Yang kedua adalah bagian dalam ruang meditasi. Ando mendesain celah bundar sekitar atap ruang meditasi. Cahaya menembus melalui celah, yang membuat atap bercahaya dan seolah mengambang. Sungguh menakjubkan, penggunaan cahaya membuat atap beton yang berat terlihat seperti mengambang di udara. Kesan mengambang tersebut mungkin melambangkan bahwa pengunjung masuk ke ruang meditasi, dan jiwa mereka yang mengambang dari dunia fana dan masuk ke dunia spiritual yang ringan.

\section{Serpentine Gallery Pavilion, Peter Zumthor}

Galeri Serpentine adalah sebuah galeri seni di Kensington Gardens, Hyde Park, pusat kota London. Sejak tahun 2000, setiap tahun pada musim panas, galeri ini menugaskan arsitek terkenal yang diakui dari seluruh dunia untuk merancang sebuah paviliun temporer di halaman galeri.

Konsep Paviliun pada tahun 2011 ini adalah 'Conclusus Hortus', ruang kontemplatif, sebuah taman di dalam taman. Pengunjung memasuki bangunan melalui hamparan rumput dan mulai tertransisi ke inti taman, sebagai tempat yang terpisah dari dunia kebisingan, lalu lintas dan bau Kota London. Ruang dalam diciptakan untuk pengunjung duduk, berjalan, dan mengamati bunga-bunga.
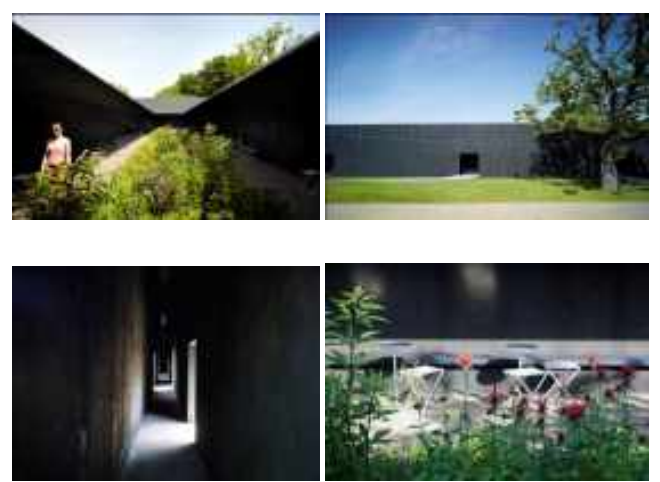

Gambar 9. Paviliun Karya Peter Zumthor di Serpentine Gallery

Disain Zumthor, menekankan aspek sensorik dan spiritual dari pengalaman arsitektur. Dari komposisi yang tepat namun sederhana dan bahan yang dihadirkan, untuk menangani skala dan efek cahaya.

Inti dari disain Peter Zumthor ini adalah pilihan olahan bahan yang digunakan untuk menciptakan ruang kontemplatif yang membangkitkan dimensi spiritual lingkungan fisik kita. Seperti biasa, tujuan estetika Zumthor adalah untuk menyesuaikan bangunan yang tujuannya justru sebagai badan fisik dan obyek pengalaman emosional.

\subsection{Konsep Dasar Ruang Kontemplasi}

Impresi dari tiap-tiap ruang yang di desain melibatkan segenap indrawi untuk menangkap impresi ruang berkaitan dengan berkontemplasi 'tahap akal', 'tahap rasa', dan 'tahap kalbu'. Setiap tahap berkontemplasi menentukan jenis kegiatan yang di wadahi sesuai dengan tahap akal yang merupakan kegiatan pengamatan, tahap rasa merupakan kegiatan penghayatan, dan tahap kalbu yang merupakan kegiatan perumusan nilai. 
Setiap kelompok kegiatan memiliki tahap berkontemplasi berdasarkan impresi ruang untuk berkontemplasi yang melibatan akal, rasa, dan kalbu. Impresi yang melibatkan 'akal' adalah tahap pengenalan atau berapresiasi terhadap seni dan budaya, baik oleh komunitas lokal maupun masyarakat luas. Pada tahap ini kegiatan yang diakomodir berkaitan dengan fungsi yang rekreatif serta fungsi pendidikan dan latihan untuk tiap-tiap jenis seni dan budaya tersebut di atas.

Berkontemplasi dengan melibatkan 'rasa' lebih pada pelayanan terhadap fungsi penikmatan oleh pengunjung. Pada tahap ini pengunjung dapat merasakan lebih lanjut untuk diam sesaat menikmati suguhan dari fasilitas seni dan budaya yang ada.

Terakhir berkontemplasi dengan melibatkan 'kalbu' adalah pelayanan fungsi oleh pelaku tiap-tiap kegiatan yang ada. Dimana pelaku kegiatan dapat menuangkan imajinasi dan intuisinya sehingga tercipta kreatifitas yang tinggi ataupun kesadaran terhadap kebenaran yang hakiki untuk menghasilkan sesuatu menjadi lebih baik.

Dalam beberapa studi banding di atas terlihat jelas bahwa keberhasilan impresi ruang untuk mempengaruhi segenap indrawi adalah permainan cahaya. Baik impresi cahaya itu sendiri, atau efek cahaya yang meninggalkan jejak berupa bayang dan bayangan, bahkan cahaya yang memberikan impresi berbeda pada material bentukan arsitektur.

Untuk kasus ruang kontemplasi seni dan budaya, pada tahap 'akal' konsep arsitekturnya berkaitan dengan material. Material yang digunakan adalah material yang dapat merefleksikan efek cahaya. Tahap 'rasa' konsep arsitekturnya berkaitan dengan bentuk, dimana cahaya dapat menciptakan bentuk bayang atau bayangan. Dan pada tahap 'kalbu' konsep arsitekturnya berkaitan dengan ruang, dimana ruang mempunyai beragam kesan karena hadirnya cahaya.

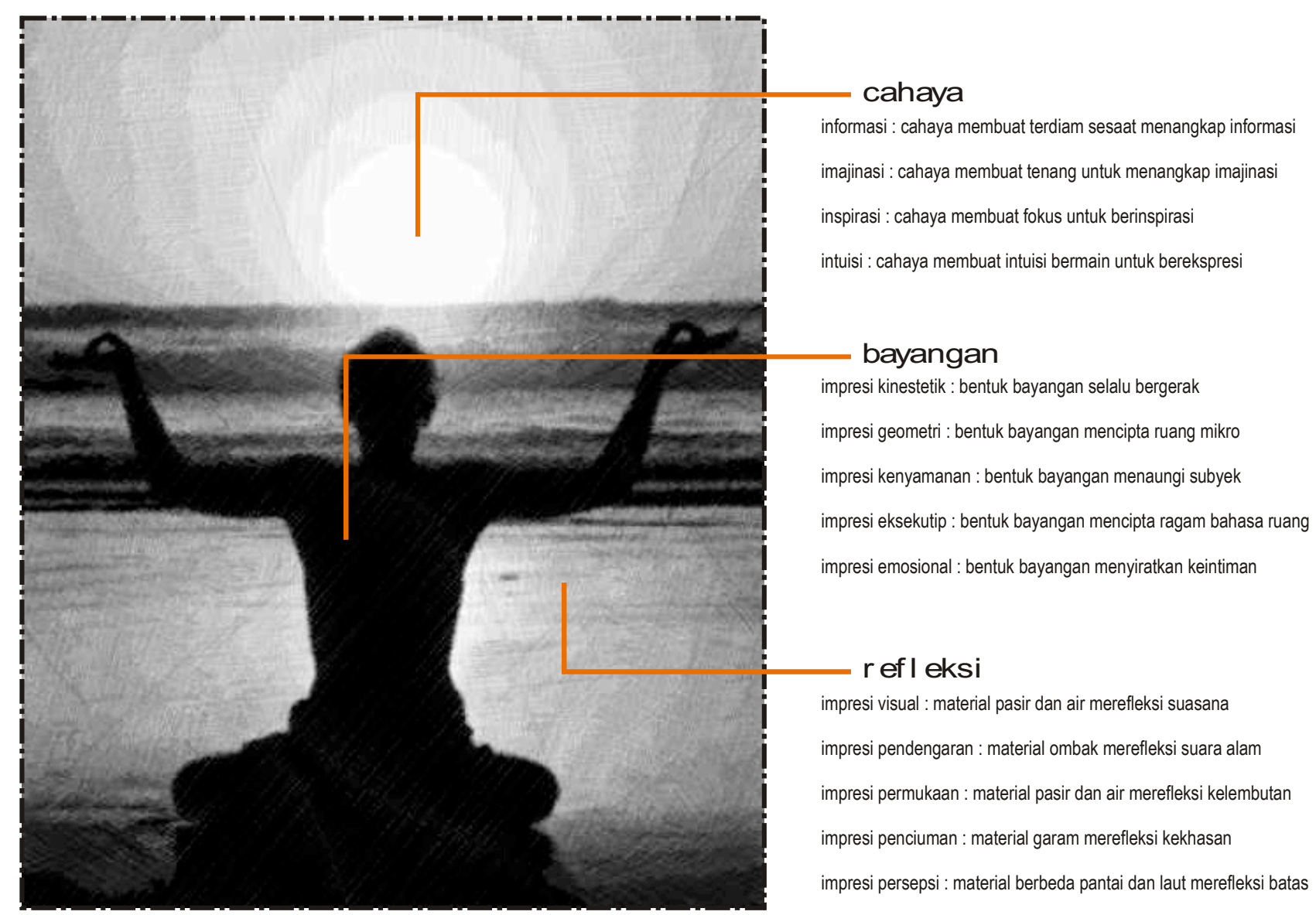

Gambar 10. Impresi Dalam Meditasi

Dapat dilihat dalam sketsa bermeditasi di pinggir pantai pada saat 'sunset' di Gambar 10 di atas, terlihat bahwa seluruh 'senses of impression' bisa dirasakan dengan bermula dari adanya sinar matahari yang lembut. Sinar matahari tersebut tertangkap dan di refleksikan oleh air yang membasahi pasir. Sinar matahari tersebut juga menciptakan bayangan yang dramatis dihadapan subjek pelaku meditasi. Ditambah dengan suara ombak yang bergemuruh dan aroma khas pasir pantai, menambah subjek masuk lebih dalam kepada pengertian terhadap kebesaran Yang Maha Kuasa. 
Analogi tersebut dapat menjadi dasar dalam konsep perencaan Ruang Kontemplasi Seni dan Budaya. Impresi yang diharapkan tertuang ke seluruh elemen bentukan arsitektural dari material pembentuk, bentuk itu sendiri, hingga cahaya yang masuk karena bentukan yang diciptakan. Sehingga terciptalah ruang yang impresif.

\subsection{Prinsip Perancangan Ruang Kontemplasi}

Dari konsep dasar dan impresi ruang diatas dirumuskan konsep arsitektural yang berkaitan dengan material, bentuk, dan ruang yang dapat mengakomodir kebutuhan berkontemplasi terhadap seni dan budaya. Berkontemplasi pada tahap 'akal' dimana peran logika, pemikiran, dan perumusannya diakomodir dengan material pembentuk dan refleksinya. Berkontemplasi pada tahap 'rasa' yang melibatkan norma, etika, adat, dan rasa indrawi manusia diakomodir dengan bentuk arsitektural dan bayangannya. Dan pada kontemplasi tahap 'kalbu' yang merupakan ruang penjelajahan jiwa yang paling dalam dan merujuk pada esensi kebenaran (keindahan) diakomodir oleh ruang arsitektural dan cahaya pembentuk impresinya.

\section{Material dan Refleksi}

1) Impresi Visual,

Secara visual, material kaca dan air dapat merefleksikan kegiatan dan suasana sekitar. Kegiatan dan suasana yang terefleksi selain memberikan kesan yang dinamis, juga memberikan kesan luas dan tanpa batas. Hal tersebut merefleksikan tingkatan permainan akal dalam menangkap informasi yang tak terbatas. Impresi visual yang tertangkap dan direfleksikan oleh material pembentuk arsitektural sebagai konsep yang mampu mengakomodir kebutuhan berkontemplasi pada tahap 'akal'.

Cahaya yang terpantul pada air yang beriak akan menciptakan efek cahaya yang bergerak dinamis, sehingga suasana ruang dipenuhi oleh informasi yang tidak statis. Apresiasi yang ditangkap tidak hanya berhenti pada tahap permainan akal, namun akan membawa 'penikmat' menuju untuk mengapresiasi lebih lanjut ke tahap permainan 'rasa'. Membawa 'penikmat' masuk lebih dalam untuk merasakan sensasi visual yang tersembunyi di balik materi yang disuguhkan.

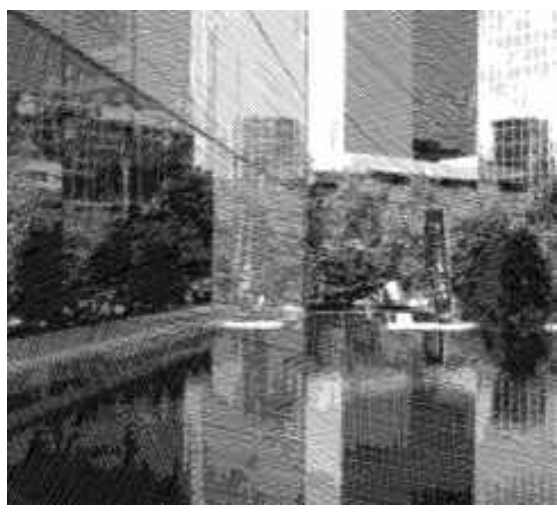

1) Impresi Visual

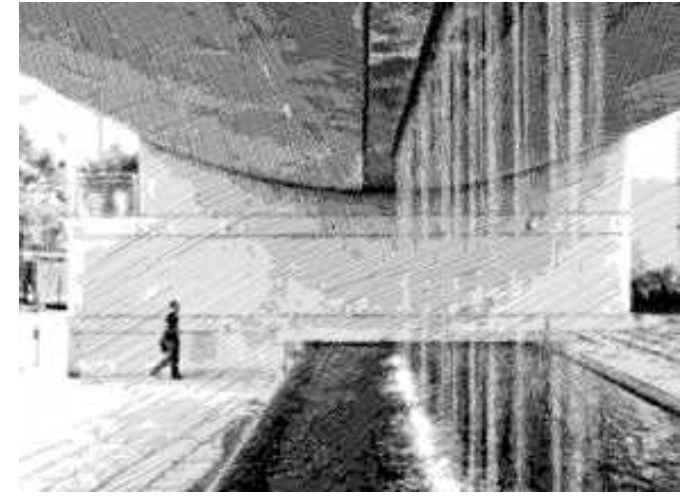

2) Impresi Pendengaran

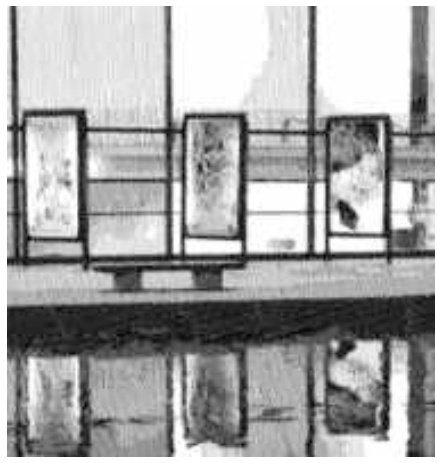

3)
Impresi Permukaan

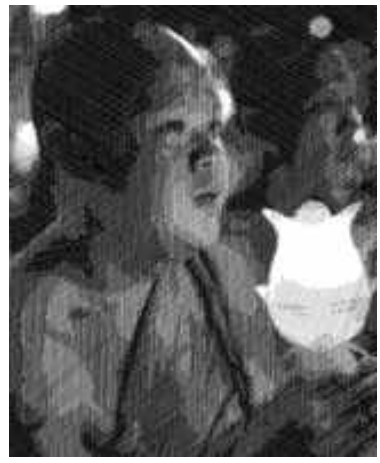

4)

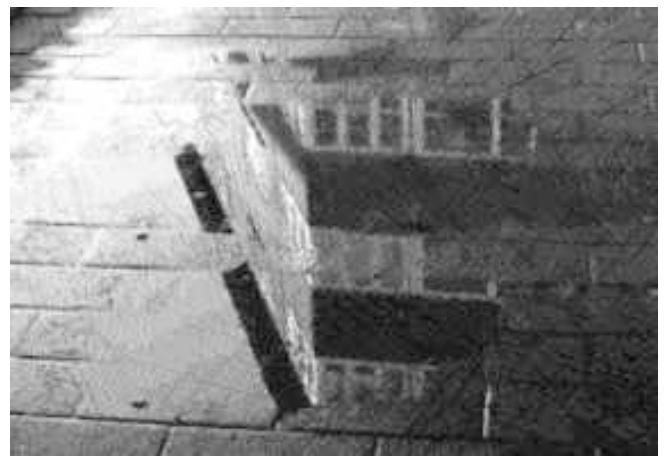

5) Impresi Persepsi

Gambar 11. Impresi Material dan Refleksi

\section{2) Impresi Pendengaran,}

Material air yang mengalir dan jatuh memberikan impresi terhadap pendengaran. Suara gemericik air masuk ke dalam bangunan dan memenuhi ruangan, sehingga mampu memberikan suasana seperti di alam terbuka (natural). Gemericik air yang mengalun menciptakan suasana teduh, lembut, sejuk, yang membawa hati dan 
pikiran untuk dapat diam sesaat menikmati suguhan seni dan budaya yang disajikan.

Air yang mengalir, sayup-sayup tertangkap oleh indra pendengaran membawa alam pikiran si Penikmat mengalun mengikuti irama air untuk menengkap pengertian yang lebih dalam terhadap sajian yang disuguhkan. Refleksi suara air mengalir merupakan impresi pendengaran yang dapat mempengaruhi akal dan pikiran penikmat untuk lebih fokus dan dapat merasakan suasana ruang yang diciptakan lebih lembut menutupi material beton yang keras.

3) Impresi Permukaan,

Material air merefleksikan kesan lembut material lain yang terpantul pada permukaan air. Material kaca merefleksikan dan mentransparansikan kesan apa adanya terhadap suasana atau material lain yang di pantulkan. Impresi permukaan yang ditawarkan pada fasilitas ini adalah ruang apresiatif yang mampu memberikan kesan lembut dan terbuka apa adanya untuk dinikmati oleh pengunjung. Kesan keterbukaan, transparansi, dan pantulan membawa penikmat untuk dapat menikmati suguhan yang ada tanpa melihat latar belakang si Penikmat dari kelompok, golongan, agama, atau etnis tertentu.

Impresi permukaan yang tercipta secara arsitektural dapat dituangkan pada kulit luar bangunan. Baik kulit luar bangunan yang menghadap ke luar site ataupun ke dalam site. Hal ini dimaksudkan untuk memberikan efek refleksi seluruh kegiatan ataupun suasana yang tercipta di luar ataupun di dalam lokasi pada level 'akal' sebagai pencerminan fungsi apresiatif.

4) Impresi Penciuman,

Indra penciuman juga merupakan salah satu aspek yang dapat membuat suasana menjadi lebih sakral. Terlihat dalam beberapa ritual keagamaan ataupun keyakinan keberadaan bunga, dupa, ataupun bokor menjadi salah satu elemen yang cukup penting dalam menjalani ritual. Dalam sketsa gambar 11-(4) terlihat dalam melakukan ritual salah satu agama merefleksikan keharuman bunga pada sebuah bokor kaca yang berbentuk bunga.

Secara arsitektural pencerminan dari impresi penciuman di refleksikan pada bentukan arsitekturalnya.

5) Impresi Persepsi,

Tingkat pengetahuan seseorang akan mempengaruhi persepsi yang terbentuk dalam akal pikirannya dari sesuatu yang dilihat dan dirasakan. Dari keempat impresi lain yang disebut di atas, suasana yang tercipta pada tahap apresiatif penikmat dibiarkan bebas untuk mempersepsikan apa yang dia lihat dan dia rasakan.

Impresi persepsi memberikan informasi awal berkaitan dengan bentukan arsitektural ataupun suasana yang diciptakan untuk para pengunjung dari berbagai latar belakang. Hasil persepsi dari tiap-tiap pengunjung menjadi salah satu aspek untuk menciptakan keingin-tahuan lebih dalam tentang seni dan budaya yang disajikan.

\section{Bentuk dan Bayangan}

1) Impresi Kinestetik,

Dari bentukan arsitektural yang tercipta selalu meninggalkan bayangan yang mempengaruhi impresi ruang. Berkaitan dengan waktu, bayangan tersebut selalu berubah sesuai dengan pergerakan matahari ataupun arah datangnya sinar. Hal tersebut menciptakan impresi kinestetik yang dapat dirasakan oleh pengunjung yang mempengaruhi suasana ruang dengan bergeraknya bayangan dari waktu kewaktu. Impresi tersebut menciptakan suasana bergerak statis yang membuat rasa nyaman untuk diam sesaat membawa akal pikiran ke arah rasa. Rasa untuk berimajinasi, berkreasi, berbuat sesuatu menjadi lebih baik. Secara arsitektural bentukan yang diciptakan harus memberikan efek bayangan yang mempengaruhi rasa 'penikmat' atau 'pelaku' pada tiap-tiap fasilitas.

Impresi kinestetik diaplikasikan terhadap desain dengan menggunakan bentukan arsitektural dengan memperhatikan arah datang sinar matahari pada siang hari dan pencahayaan buatan pada malam hari.

2) Impresi Geometri,

Datangnya sinar terhadap sebuah benda akan merefleksikan bentuk yang terdistorsi. Gelap-terang yang tercipta akan membentuk geometri sesuai dengan objek yang terkena cahaya. Gelap merupakan bayangan dari objek, dan terang merupakan cahaya yang tak terhalang oleh objek. Bentuk geometri yang terdistorsi tersebut akan selalu berubah sesuai dengan arah datangnya cahaya. Hal ini memberikan pengalaman yang berbeda-beda sesuai dengan waktu datangnya penikmat atau pelaku. Impresi geometri tersebut diharapkan tersimpan dalam memori dan akan berubah sesuai dengan waktu datangnya penikmat atau pelaku.

Perubahan bentuk geometri dari bayangan tersebut mampu memberikan suasana yang berbeda dari waktu kewaktu dan dapat mempengaruhi rasa pengunjung untuk minikmati suasana berbeda setiap waktunya.

3) Impresi Kenyamanan,

Berteduh, salah satu rasa nyaman yang ingin di dapat pada saat hari terik. Berteduh pada waktu terik selalu dilakukan di balik bayangan sebuah benda yang terkena sinar matahari. Impresi kenyamanan dari bayangan ini merupakan impresi yang harus diakomodir untuk membuat pengunjung merasa nyaman dalam melakukan aktivitasnya. Rasa nyaman yang tercipta memberikan suasana 'saat teduh' sebagai implementasi dari ritual berbagai keyakinan yang dibutuhkan oleh pelaku ritual.

'Saat teduh' yang tercipta merupakan impresi kenyamanan dari hasil olahan bentuk arsitektural yang membuat pengunjung betah untuk melakukan ritual berekspresi dan berkreasi terhadap seni dan budaya yang ada. 
Impresi kenyamanan yang menghantarkan pelaku menjadi betah dalam melakukan ritual berekspresi dan berkreasi, dapat diakomodir oleh bentukan arsitektur yang menghasilkan bayangan untuk tempat berteduh baik subjek ataupun objek pelaku seni dan budayanya.

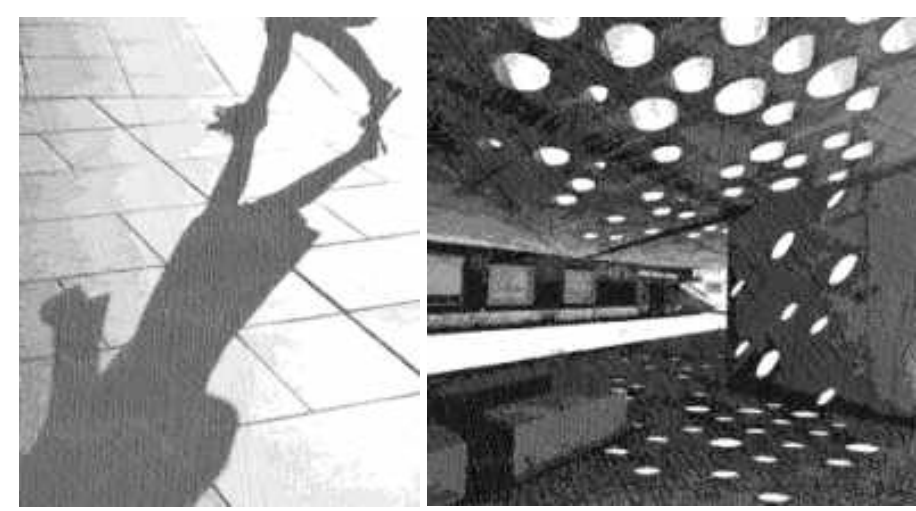

1) Impresi Kinestetik

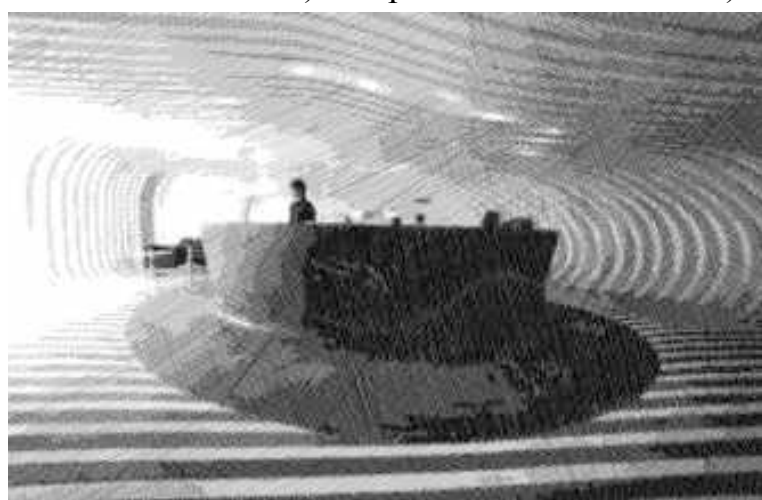

3) Impresi Kenyaman

2) Impresi Geometri

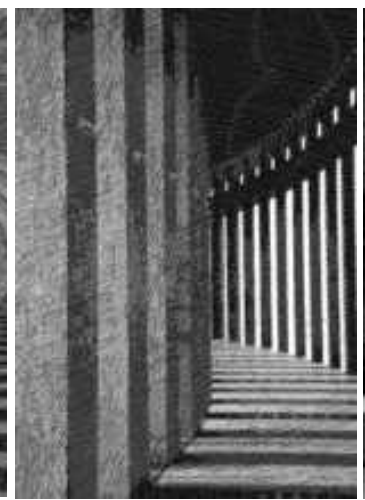

4) Impresi Eksekutif.

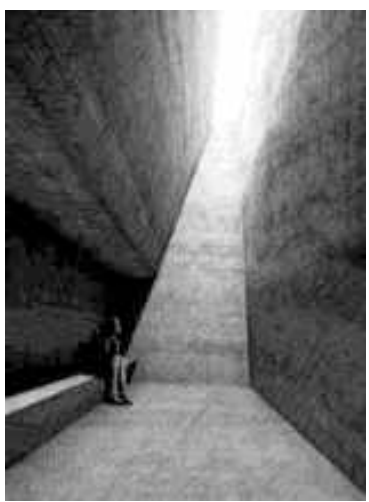

5) Impresi Emosional

Gambar 12. Impresi Bentuk dan Bayangan

\section{4) Impresi Eksekutif,}

Bayangan yang terbentuk dari sesuatu yang berulang-vertikal akan memberikan kesan agung. Keagungan suatu ruang akan membuat suasana eksekutif bagi mereka yang berada dalam ruang tersebut. Impresi ekskutif gelapterang dari sinar dan bayangan membuat suasana ruang lebih tenang untuk berkontemplasi.

Rasa memiliki ruang atau rasa kebersamaan dalam sebuah ruang menciptakan kesan eksekutif dari kegiatan yang dilakukan. Memiliki dan kebersamaan merupakan rasa untuk lebih percaya diri dalam berkreasi atau berekspresi. Dengan demikian pengunjung dapat melakukan aktivitasnya dengan lebih baik secara mandiri ataupun berkelompok.

Impresi eksekutif diciptakan oleh cahaya dan bayangan yang memenuhi ruang menjadi elemen arsitektural untuk menjadikan suasana ruang lebih intim namun khidmat. Unsur keintiman yang khidmat didisain oleh lubang-lubang masuknya cahaya ke dalam ruang secara vertikal. Sehingga cahaya yang masuk ke dalam ruang membentuk garis-garis yang harmonis memenuhi ruang. Namun untuk mencapai kekhidmatan ruang, unsur bayangan haruslah lebih mendominasi unsur cahaya.

5) Impresi Emosional

Sisi emosi dalam berkreasi dan berekspresi merupakan sisi yang menentukan kualitas hasilnya. Dengan demikian impresi emosional berperan penting dalam mengakomodir kebutuhan pengunjung untuk berkontemplasi. Emosi yang tidak menentu dari tiap individu ataupun emosi yang berbeda-beda dari tiap individu dalam sebuah kelompok haruslah disamakan dan diselaraskan dengan tujuan berkontemplasi.

Bayangan yang menaungi individu atau bayangan di sekitar individu membuat garis-garis imajiner yang menciptakan ruang privat. Ruang privat tersebut akan menyentuh sisi emosi bagi tiap individu untuk lebih tenang dan fokus dalam menghayati dan meluapkan semua yang dirasakan ke dalam bentuk kreasi ataupun ekspresi.

Impresi emosional yang tercipta dari naungan bayangan merupakan elemen arsitektur yang dapat diimplementasikan dalam disain ruang kontemplasi seni dan budaya, sehingga rasa eksistensi diri pengguna terbentuk dengan adanya ruang-ruang privat secara imajiner. 


\section{Ruang dan Cahaya}

1) Informasi,

Diam beberapa saat (motionless), merupakan salah satu cara dalam berkontemplasi. Dengan diam individu dapat menangkap informasi secara maksimal, dengan diam pelaku dapat melakukan pengamatan, dengan diam terjadi penghayatan, dan dengan diam dapat melakukan simpulan nilai. Informasi sensori fisik yang merupakan transisi dari fenomena empiris dan fenomena ilmiah dapat dicapai dengan diam untuk mengoptimalkan segenap indrawi.

Cahaya yang masuk ke dalam ruang melalui celah sempit dapat memberikan informasi sesuai gambaran yang ingin dicapai. Seperti gambar di bawah ini, cahaya yang terbentuk dari bentuk salib dari desain Tadao Ando menggambarkan bahwa ini adalah sebuah gereja.

Cahaya yang menerangi objek dalam pagelaran seni, baik itu seni rupa ataupun seni lainnya, terlihat bahwa peranan cahaya sangat menentukan keberhasilan dalam memberikan informasi. Dalam ruang untuk berkontemplasi cahaya yang diberikan tidaklah berlebihan, dalam arti cahaya yang berperan cukup pada objek ataupun bentukan yang ingin dicapai dengan keberadaan cahaya itu sendiri.

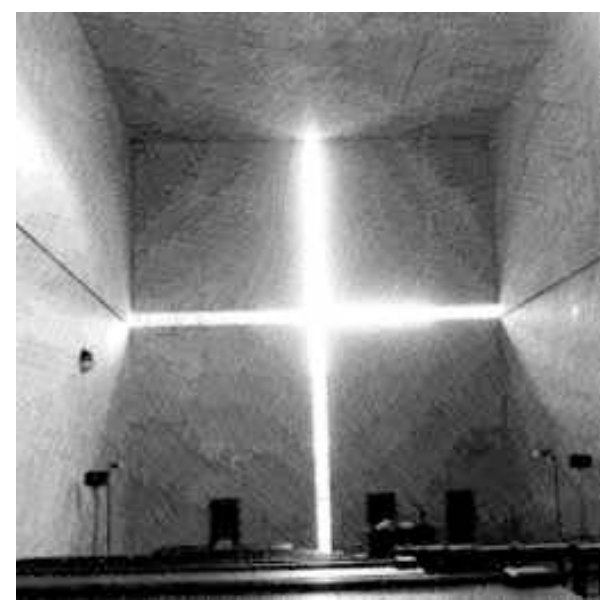

1) Cahaya Memberi Informasi

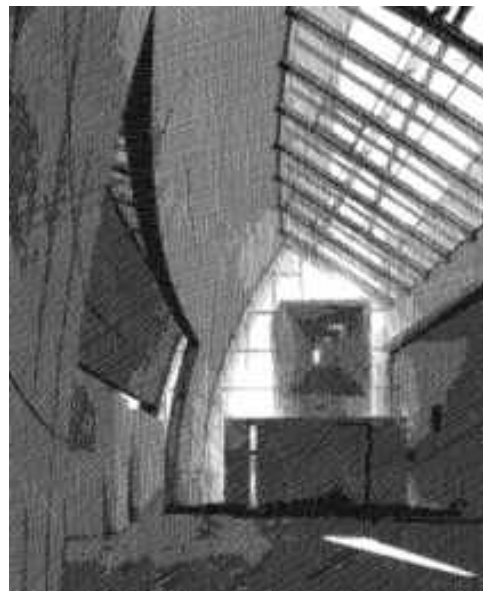

3) Cahaya Menjadi Inspirasi

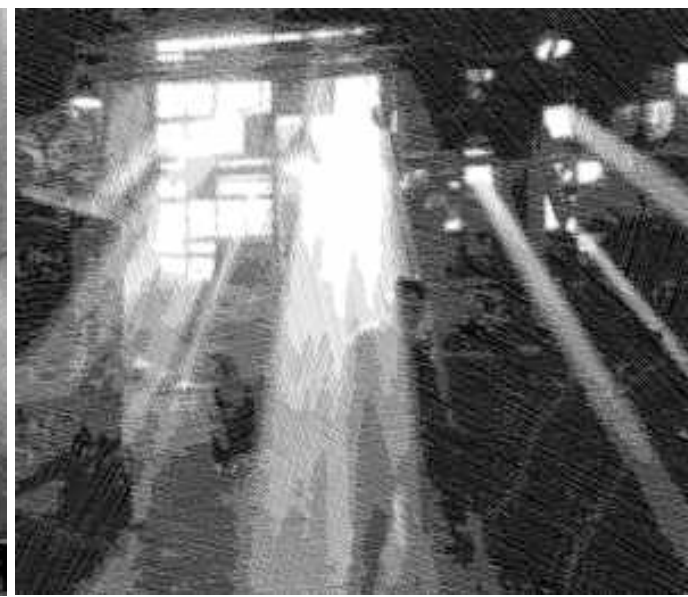

2) Cahaya Menciptakan Imajinasi

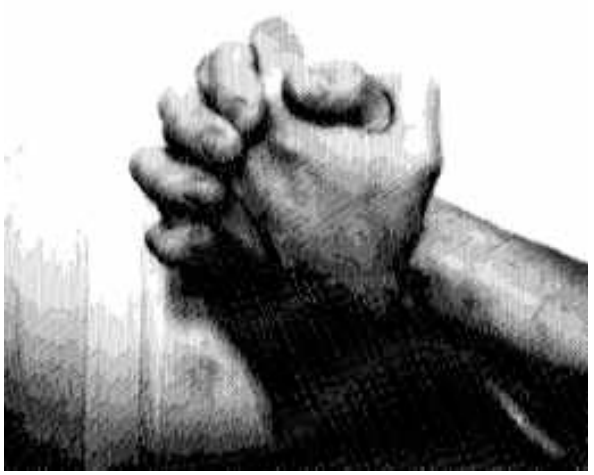

4) Cahaya Melibatkan Intuisi

Gambar 13. Peran Cahaya

2) Inspirasi,

Proses 'intensification' atau 'distillation' terhadap fenomena, akan membawa pada penemuan 'gestures' sebagai indikasi dari 'intention'. Sehingga diperlukan keterlibatan manusia dan diwujudkan dalam ekspresi 'gestures sketches'. Berkontemplasi mempunyai tujuan untuk menciptakan sesuatu menjadi lebih baik. Fokus dalam melakukan atau menghayati sesuatu diyakini dapat menginspirasi akal, rasa, dan kalbu seseorang untuk berkreasi dan berekspresi.

Cahaya yang menerangi subjek atau objek, pelaku atau hasil sebuah seni atau kegiatan, akan memberikan informasi tentang sebuah fenomena. Cahaya akan memberikan informasi apa adanya dan mengekspresikan 'gestures sketches' terhadap benda/seseorang yang diterangi yang akan ditangkap oleh pengamat. 


\section{3) Intuisi,}

Hasil kreativitas potensi intuisi merupakan penemuan fenomena yang hakiki yang membawa pada kedalaman prinsip melalui proses penilaian intuitif. Dalam hal ini cahaya hasil dari unsur api menjadi media untuk mendapatkan penilaian intuitif terhadap fenomana yang ingin dicapai. Cahaya menjadi sarana bisikan kalbu, ilham, sebagai sarana kesanggupan dalam mencapai pemahaman secara langsung tanpa memalui proses berpikir. Ekspresi cahaya berperan penting dalam membangkitkan sisi kalbu yang secara intuisi menganggapnya sebagai kehadiran Yang Maha Kuasa.

Peran cahaya dalam ruang kontemplasi melibatkan intuisi menganggap ruang menjadi sakral. Dalam disainnya cahaya yang mempengaruhi intuisi tidaklah harus berlebihan, haruslah fokus dalam satu atau beberapa titik yang akan menimbulkan kesan keagungan Yang Maha Kuasa.

\subsection{Implementasi Konsep}

Berkontemplasi pada tahap akal adalah berkontemplasi dalam tahap pengamatan. Untuk ruang-ruang kontemplasi tahap ini merupakan ruang bebas berpersepsi, ruang yang penuh informasi, ruang padat interaksi antar sesama pengguna, sehingga persepsi, informasi dan interaksi mengenai seni dan budayanya dapat langsung ditangkap. Untuk memperkuat impresi ruang, selain kegiatan yang ada dalam ruang, elemen kaca dan air menjadi elemen pembentuk suasana ruang. Elemen kaca pada dinding vertikal dapat merefleksikan seluruh kegiatan yang ada, serta elemen air yang bergerak, gelombangnya dapat terpantul pada bidang horizontal atas dan dinding vertikal massif, sehingga ruang menjadi lebih dinamis dan hidup.

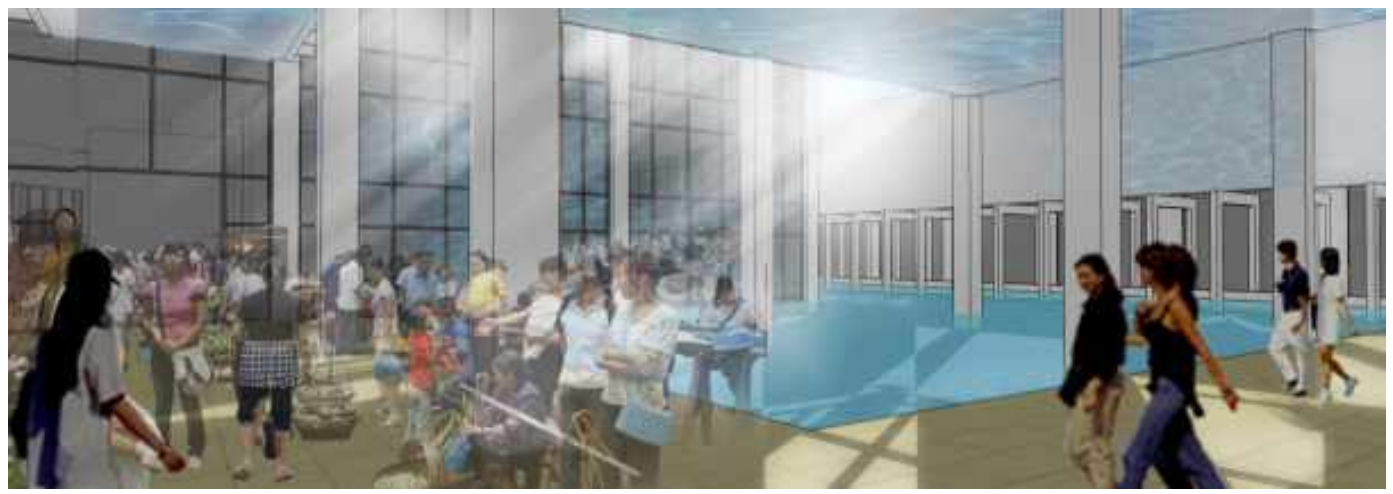

Gambar 14. Cahaya dan Eksistensi Ruang

Salah satu contoh seperti pada ruang transisi antara aktifitas luar bangunan dan dalam bangunan, dimana seluruh seni dan budaya yang disajikan terrefleksi di dinding kaca pelingkup bangunan, serta air bergerak pada kolam terpantulkan dan menari di plafon ruang transisi membuat suasana ruang menjadi hidup. Ruang menjadi bukan hanya sebuah wadah, namun ruang menjadi hidup, bergerak, bahkan menari mendukung hiruk pikuknya kegiatan.

Kualitas ruang kontemplasi tahap 'rasa' bermain dengan cahaya dan bayangan. Sesuai dengan berkontemplasi pada tahap penghayatan, kehadiran cahaya dan bayangan memisahkan antara sesuatu yang harus diamati dengan yang mengamati, sehingga si pengamat dapat diam sesaat untuk menghayati yang diamatinya. Cahaya pada ruang ini berperan sebagai penguat obyek, mengatur arah gerak, dan pemisah antar subyek dan obyek.

Cahaya dan bayangan pada ruang kontemplasi tahap 'rasa' adalah sebagai penguat impresi ruang. Dimana ruang yang sudah berwujud 3 dimensi dengan material yang mendominasi bangunan, diperkuat oleh hadirnya cahaya dan bayangan. Cahaya yang bergerak sesuai dengan waktu pada siang hari dapat membentuk dimensi ke-empat, masuk melaui celah sempit material pembentuk ruang. Cahaya bergerak, bayangan terbentuk, sisi gelap-terang yang kontras, membuat indra dan rasa menjadi tenang untuk dapat masuk dalam tahap penghayatan.

Cahaya dan bayangan membentuk suasana intim untuk tiap kegiatan baik itu kegiatan secara individu ataupun kelompok. Keintiman tersebut yang menciptakan dan menyederhanakan persepsi dalam melaksanakan proses penghayatan. Cahaya dan bayangan dituangkan keseluruh kegiatan berkontemplasi pada tahap 'rasa', baik itu kegiatan pasif ataupun kegiatan aktif di masing-masing ruang atau fassilitas. 


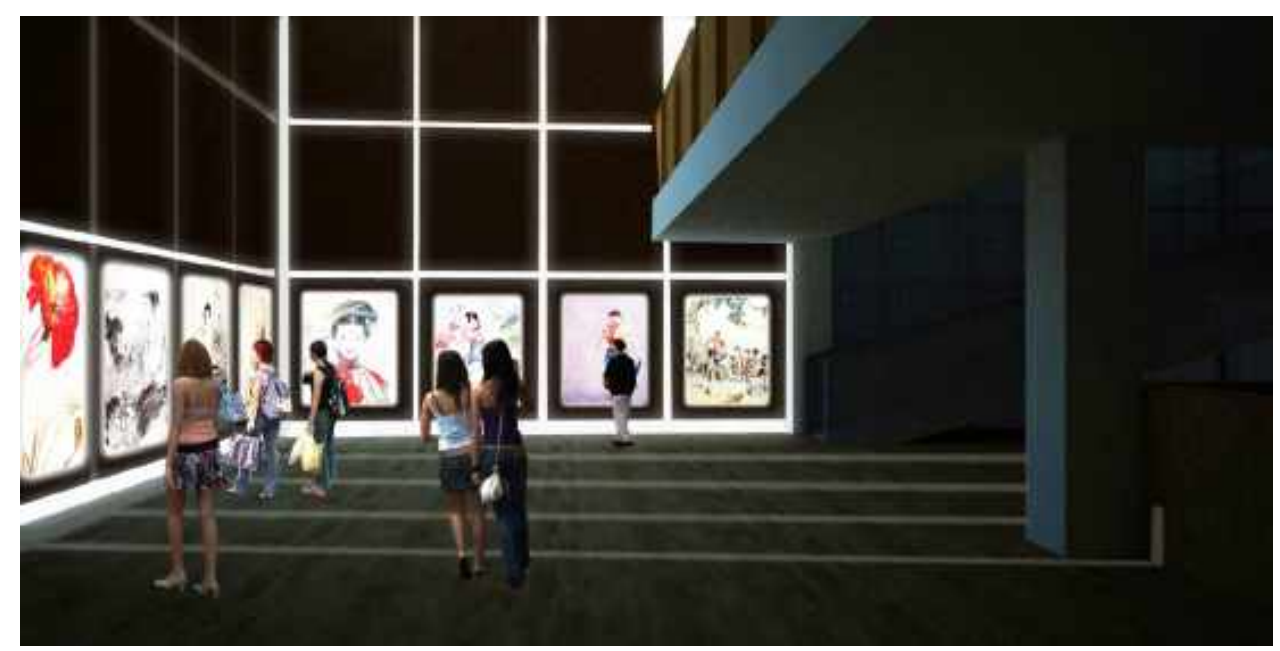

Gambar 15. Cahaya dan Eksistensi Obyek

Seperti gambar ruang pamer 2 dimensi di bawah ini, cahaya yang masuk malu-malu ke dalam ruang menciptakan batas-batas sisi gelap-terang. Para pengamat hasil karya seni tersebut dapat memposisikan diri di sisi gelap untuk diam sesaat menikmati dan menghayati karya tersebut. Garis-garis cahaya yang masuk ke dalam ruang menciptakan rasa untuk maju selangkah demi selangkah menuju karya-karya lainnya.

Cahaya yang keluar dari obyek yang diamati mencoba meneriakkan eksistiensinya bahwa dia ada, dia indah, dan dia menawan untuk dihayati, dinikmati, bahkan untuk dimiliki. Bayang dan bayangan yang terbentuk menihilkan nilai, bahwa hidup tidak ada, tidak indah, dan tidak menawan tanpa diisi oleh eksistiensi seni yang sejatinya merupakan ekspresi dari nilai keindahan.

Sebagai ruang untuk berkontemplasi tahap tertinggi yang melibatkan kalbu, kualitas ruang bermain pada tahap persepsi jiwa. Akal dan rasa yang sudah terbentuk dalam pribadi tiap-tiap individu merupakan modal utama untuk masuk lebih dalam mempengaruhi jiwa untuk merumuskan nilai-nilai. Pada ruang-ruang ini cahaya menjadi sumber inspirasi pembentuk suasana ruang. Cahaya menjadi elemen terpenting untuk meningkatkan eksistensi diri.

Kualitas ruang kontemplasi pada tahap ini menempatkan posisi cahaya sebagai sarana mencapai tujuan berkontemplasi, cahaya sebagai sarana berekspresi. Cahaya yang menyinari subyek pelaku seni olah suara, cahaya yang mengatur gerak seni tari, cahaya yang membentuk ruang pribadi pelaku seni rupa, dan cahaya yang membatasi ruang individu pelaku meditasi sebagai pengejawantahan nilai konsepsi terhadap desain ruang kontamplasi seni dan budaya yang ada.

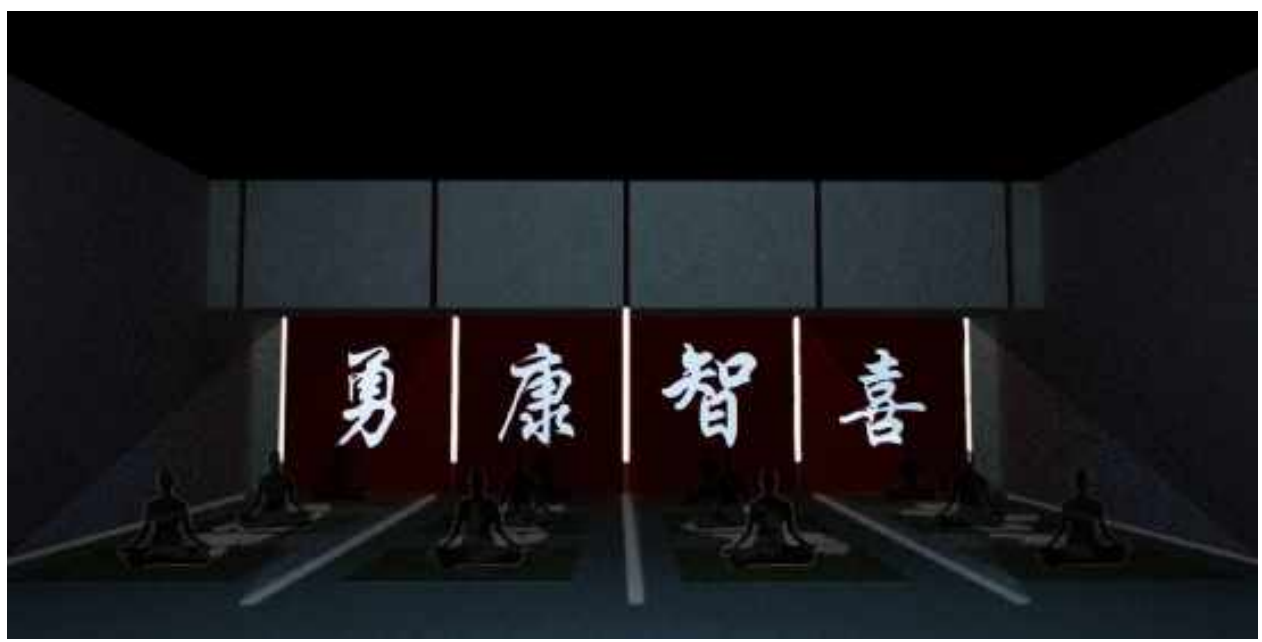

Gambar 16. Cahaya dan Eksistensi Subyek

Gambar ruang latihan yoga di atas, menggambarkan terciptanya ruang-ruang individu dengan masuknya cahaya yang memberi batas antar pelaku yoga. Symbol dari tulisan China tempat masuknya cahaya untuk menerangi deretan para pelaku juga memberikan makna tersendiri sesuai dengan arti dari tiap-tiap tulisan. Pelaku yoga pertama 
kali masuk ke dalam ruang dapat mengartikan tulisan tersebut sesuai dengan persepsinya masing-masing. Kebenaran, kesehatan, kebebasan, dan kebahagian dari arti tulisan tersebut dapat dipersepsikan secara masingmasing, dari kiri ke kanan, atau dari kanan kekiri. 'Kebenaran' dalam hidup akan menciptakan 'kesehatan' jasmani dan rohani sehingga terbentuk 'kebebasan' jiwa untuk menggapai 'kebahagaiaan'. Atau 'kebahagian' buah dari 'kebebasan' menentukan sikap yang dilandasi oleh 'kesehatan' jasmani dan rohani sebagai kristalisasi dari 'kebenaran'.

\section{Kesimpulan}

Melakukan intervensi terhadap strategi perkotaan, dengan mensinergikan kepentingan budaya lokal terhadap eksistensinya dalam sebuah kota, diharapkan dapat memberikan konsepsi yang mampu menjawab persoalan yang ada. Intervensi yang diberikan berupa ruang kontemplasi seni dan budaya diharapkan mampu mengakomodir kebutuhan komunitas lokal secara khusus dan juga yang memberikan efek positif dalam skala kota.

Berkontemplasi adalah kegiatan bertahap yang melibatkan akal pada tahap pengamatan, rasa pada tahap penghayatan, dan kalbu pada tahap perumusan nilai. Seluruh kegiatan tersebut secara arsitektural dapat diakomodir oleh ruang yang mengimpresikan masing-masing ruang sesuai dengan pentahapan yang mempengaruhinya. Dimana berkontemplasi pada tahap akal bermain dengan persepsi konsepsi ruang bagi pengamat, pada tahap rasa bermain dengan ego pelaku dan pengamat, dan pada tahap kalbu bermain dengan jiwa pelaku kegiatan.

Impresi sensorik yang diterjemahkan dalam ruang kontemplasi seni dan budaya menjadi satu penyelesaian arsitektur yang membuktikan bahwa; Arsitek dapat men-sakral-kan lokasi dengan mengumpulkan impresi sensorik yang bermakna bagi individu dan lokasi, dan menuangkan impresi tersebut ke dalam solusi desain --- sehingga tercipta sebuah "Ruang Kontemplasi".

Cahaya merupakan salah satu unsur yang dapat menguatkan impresi sebuah ruang. Sehingga karya arsitektur tidak melulu hanya menjawab kebutuhan akan ruang dalam bentuk fisik, namun bagaimana ruang yang berupa benda mati menjadi hidup agar dapat menjalankan tugasnya untuk melindungi, mengayomi, menentramkan, mengamankan, bahkan mengisolasi pelaku dalam ruang. Cahaya mampu menciptakan dimensi keempat dalam sebuah ruang.

Cahaya merupakan elemen arsitektur yang tidak berbentuk fisik yang mampu menguatkan impresi elemen fisik arsitektural yang berupa material, bentuk, dan ruang. Kehadiran cahaya mengimpresikan material arsitektur menjadi hidup, bentuk arsitektur menjadi terdistorsi, dan ruang arsitektur menjadi ekspresif. Sehingga dapat disimpulkan bahwa cahaya mampu memberikan impresi sensorik untuk diterjemahkan dalam solusi desain ruang kontemplasi seni dan budaya.

Diharapkan kekuatan impresi cahaya dalam mempengaruhi elemen fisik arsitektur di penelitian ini, mampu menjadi konsepsi dalam penyelesaian olahan arsitektur lainnya yang berkaitan dengan men-sakral-kan individu dan lokasi untuk menjadi solusi desain.

Konsepsi persepsi ini hanya membaca kebutuhan subyek dan menempatkan posisi obyek sesuai dengan fenomena kebutuhan berkontemplasi yang diharapkan, dan mempengaruhi subyek sebagai sarana/ kendaraan 'being in the world'.

Dan akhirnya perlu dilakukan penelitian lebih dalam untuk memperoleh kekuatan cahaya sebagai elemen pembentuk arsitektur dalam penyelesaian detail desain sebuah ruang arsitektur yang impresif.

\section{Daftar Pustaka}

Bachelard, Gaston, (1969), The Poetics of Space, trans. Maria Jolas, Boston: Beacon Press.

Basuki, Kelik Hendro, (2012), Tesis: Ruang Kontemplasi Pada Paviliun Seni dan Budaya Tionghoa di Kota Teluk Betung, ITB, Bandung.

Helm II, William Carrie. (2007), Numinous space; towards an architecture of contemplation, Buffalo: State University of New York.

Lawson, Bryan, (2001), The Language of Space, Architectural Press, London.

Liu, Shengli (session 5); Merleau-Ponty's Phenomenology of Space, The $3^{\text {rd }}$ BESETO Conference of Philosophy, Peking University.

Santosa, Harry. Imajinasi dan Kreatifitas (Bagian Pertama). inherent.brawijaya.ac.id/vlm/login/index.php: Diunduh pada tanggal 29 September 2010 pukul 1:18AM.

http://althouse.blogspot.com

www.arscape.com

www.cen-zhang.com

www.serpentinegallery.org

www.worldarchitecturenews.com 